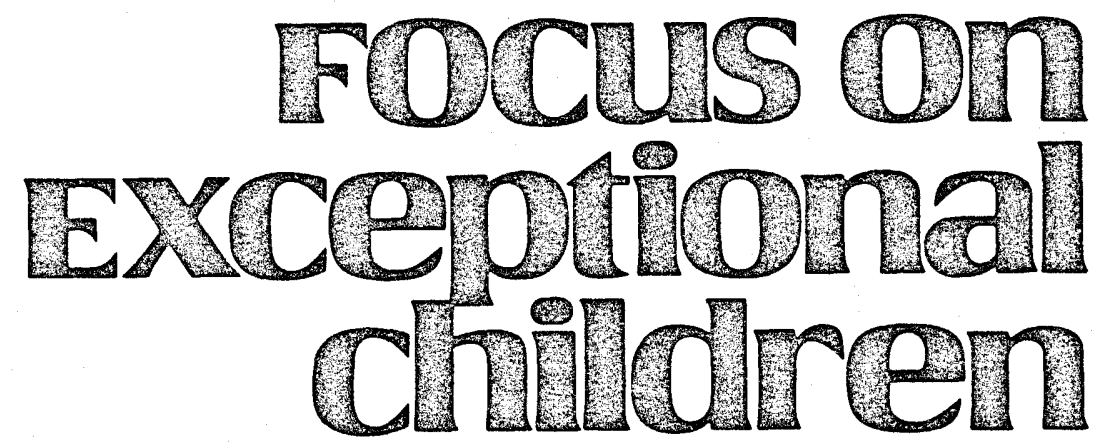

\title{
Motivation and Mildly Handicapped Learners
}

\author{
Teresa A. Mehring and Steven E. Colson
}

Motivation affects learning, and learning affects motivation (Sprinthall \& Sprinthall, 1987). Regular educators and special educators daily are faced with questions regarding motivation in the students for whom they are responsible. What factors influence students' motivational levels? Can a teacher motivate students? What techniques are effective in motivating students?

The school can contribute to development of emotional and motivational problems in very specific ways (Hallahan \& Kauffman, 1988; Paget, Nagle, \& Martin, 1984; Pullis $\&$ Cadwell, 1985). Teachers may be insensitive to individual student needs; they may hold expectations for achievement or conduct that are too high or too low; and they may communicate to the student who does not meet expectations that he or she is inadequate or undesirable. In addition, instruction may be offered in skills for which the student has no real or imagined use. All of these factors may influence the level of motivation that a regular or special education student brings to the learning environment.

Despite the critical link between motivation and learning, little research has been conducted to investigate this correlation in mildly handicapped students. Investigating the effects of motivation on school success and learning in students with mild learning and behavior deficiencies (mental retardation, learning disabilities, and behavior disorders) could provide important information to special and regular educators.

Several researchers have found that motivation to learn differs in students with mental retardation (MacMillan, 1982; Polloway \& Epstein, 1985; Polloway \& Smith, 1983; Robinson \& Robinson, 1976; Zigler, 1962). After experiencing failure, mentally retarded students tend to display reduced motivation and lack efficient learning even on simple tasks. Reschly (1987) calls this tendency the "failure set phenomenon" (p. 43). Individuals with mental retardation also tend to attribute success or failure to external variables (luck, difficulty of the task) rather than to internal factors (personal ability or amount of effort expended on the task).

Research with students who have learning disabilities (LD) has reported motivation and attribution deficits similar to those found in investigations with students who have mental retardation. Adelman and Taylor $(1983,1984)$ reported that LD students display an external locus of control for reinforcement and tend to attribute success to external factors. Deshler, Schumaker, and Lenz (1984) emphasized the existence of motivation factors that must be considered in developing interventions with LD students.

Teresa Mehring is an Assistant Dean, the Teachers College, Emporia State University. Steven Colson is an Adjunct Professor of Special Education and an Educational Diagnostician, Children's Rehabilitation Unit, University of Kansas Medical Center. 
Most students with behavior disorders (BD) are also underachievers at school, as measured by standardized tests. Students who are affected by a behavior disorder usually do not achieve at the level expected for their mental age, and they relatively seldom achieve academically advanced performance. Some children are already dysfunctional when they come to school. Others develop disorders during the school years-perhaps in part because of damaging experiences in the classroom itself (Hallahan \& Kauffman, 1988).

Most human motives are learned or acquired. Motives also affect perception. Many theorists have attempted to explain where motivation comes from and how it can be changed. An understanding of current motivation theories is critical to special education teachers, school psychologists, and regular classroom teachers who work with mildly handicapped learners. Theory assists us in understanding why some students display certain behaviors-behaviors that we often call "lack of motivation."

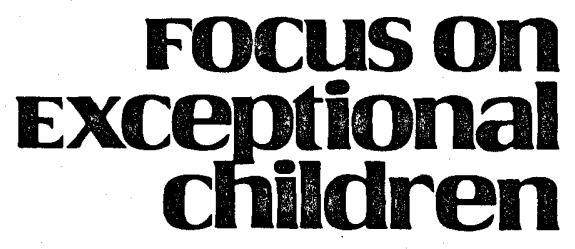

ISSN 0015-511X FOCUS ON EXCEPTIONAL CHILDREN (USPS 203-360) is published monthly except June, July, and August as a service to teachers, special educators, curriculum specialists, administrators, and those concerned with the special education of exceptional children. This publication is annotated and indexed by the ERIC Clearinghouse on Handicapped and Gifted Children for publication in the monthly Current Index to Journals in Education (CIJE) and the quarterly index, Exceptional Children Education Resources (ECER). It is also available in microfilm from Xerox University Microfilms, Ann Arbor, MI. Subscription rates: Individual, \$27 per year; institutions, $\$ 36$ per year. Copyright (C) 1990, Love Publishing Company. All rights reserved. Reproduction in whole or part without written permission is prohibited. Printed in the United States of America. Second class postage is paid at Denver, Colorado. POSTMASTER: Send address changes to:

\section{Love Publishing Company \\ Executive and Editorial Office \\ 1777 South Bellaire Street \\ Denver, Colorado 80222 \\ Telephone (303) 757-2579}

Edward L. Meyen

University of Kansas Georgia State University
Glenn A. Vergason

Richard J. Whelan

University of Kansas Medical Center

Stanley F. Love

\section{MOTIVATION THEORIES}

Not until the early 20th century did anyone experimentally validate the link between learning and motivation. In the 1980s virtually all psychologists and an increasing number of regular and special educators have become concerned with the impact of motivation variables on human behavior. Implicit in the literature on underachievement and overachievement is the assumption that motivation and emotional variables play a crucial, if not the crucial, role in academic success.

\section{Instinct Theory}

Before observations of other cultures by anthropologists Margaret Mead and Ruth Benedict, many early Western psychologists thought that what they observed in their own culture was true the world over. Because it was assumed that motives such as competition, power, status, approval, and achievement were present among all people everywhere, the term instinct was used. Early in this century McDougall (1908) authored the first book on the subject, titled Social Psychology. In it, he stated that all social life was the result of inherited instincts. According to McDougall, people were destined to play out preprogrammed instincts that were built into their biological natures. Students achieved academically because of an achievement instinct. Students not so blessed were doomed to a school life of academic frustration, and nothing could be done to change it.

By the mid 1920s psychologists had dismissed instinct theory as unscientific and ludicrous. We now know that social motives differ widely throughout the world and that social motives are learned or acquired, not inherited.

\section{Needs/Drives Theory}

According to needs/drives theory, motivation has two identifiable components: needs and drives. Needs are based on some deficit within the person. The deficit may be physiological or psychological. Physiological needs are obvious-water, food, sex, sleep, warmth, and so on. Psychological needs are more subtle and less easily identified-approval, affection, power, prestige, and so on.

Drives are based on needs, but they have the added feature of an obvious change in behavior; they imply motion of some sort. When we experience a drive, we are motivated to pursue actions that will lead to a reduction in the drive. A good example might be hunger. If an individual 
goes without food for a while, the result is discomfort or internal tension. This drive motivates the individual to obtain food. Eating reduces the drive and restores physical and psychological balance.

All humans are born with a small set of unlearned biological drives. Twelve biological motives that Madsen (1973) and others have described are:

$\begin{array}{ll}\text { hunger } & \text { excretion } \\ \text { thirst } & \text { oxygen } \\ \text { sex } & \text { rest/sleep } \\ \text { nurturance (parenting) } & \text { activity (stimulation/arousal) } \\ \text { body temperature } & \text { security } \\ \text { pain avoidance } & \text { aggression }\end{array}$

These biological motives gradually develop into a larger, more diverse set of drives acquired through learning. Murray (1938) referred to learned drives as being psychogenic. According to Murray, most individuals have drives for achievement, recognition, affiliation, dominance, acquisition (of possessions), exhibition, and play.

Maslow (1970) postulated that all humans are motivated to satisfy or reduce a common set of needs that are qualitatively different and that could be arranged hierarchically on a scale from low to high priority These are given in Figure 1. When needs at the physiological level are satisfied, an individual becomes concerned with higher-level needs. Satisfaction of a level of needs activates needs at the next level.

Being Needs

self-actualization (realization of potential) aesthetic (order and beauty)

cognitive (knowledge and understanding)

esteem (achievement; gaining of recognition, respect, status)

Deficiency Needs belonging and love (affiliation and acceptance)

safety and security (long-term survival and stability)

survival/physiological (hunger, thirst, etc.)

\section{FIGURE 1}

Maslow's Hierarchy of Needs

From A. H. Maslow, 1970, Motivation and Personality (2nd ed.) (New York: Harper \& Row).
Maslow's theory may be identified by teachers who note that hungry students are less likely to pay attention in school than those who have had enough to eat. Even if they obtain a good meal, children who have experienced hunger are likely to experience the hunger drive as a continuing force and often begin planning how to obtain their next meal as soon as they finish eating. Students who are physically uncomfortable for any reason are less likely to be attentive because they are preoccupied with attempts at reducing their discomfort.

Safety and security are two other needs identified by Maslow. Infants and children need to satisfy safety and security needs almost daily. During their early years children are relatively helpless and most in need of stable and orderly environments. When a child's or an adolescent's world is disrupted suddenly by loss of a parent through divorce, serious illness, or death, psychological security needs often dominate. Children are easily frightened by strange environments or environments in which they feel threatened.

Once children feel safe, they turn toward affiliation needs to achieve fulfillment. Friendships, love relationships, and group acceptance emerge as dominant concerns. According to Maslow, if an individual has difficulty satisfying love and belonging needs, maladjustment-and sometimes psychopathology-may result. Students who have difficulty getting along with their classmates or teachers often have trouble reaching their academic potential. School is the first real testing ground for establishing their place among children. If they fail in social relationships, school can become a hostile environment associated only with fear and anxiety. Maslow suggested that teachers should perceive school not only as a place where students learn facts and skills but also as a place where they can develop important interpersonal relationships.

The fourth need Maslow identified is self-esteem. Esteem needs involve recognition as a human being. These needs include self-respect as well as respect from others. From self-respect comes confidence, independence, and freedom. Respect from others generates a sense of appreciation and prestige. If these needs are not satisfied, children become preoccupied with their perceived inadequacies and with possible rejection by others. Teachers should provide opportunities for students to learn to respect themselves. One of the most important roles a teacher plays is that of model. Teachers who relate to students honestly and respectfully tend to generate this attitude in their students.

When the needs described so far are more or less satisfied, individuals turn to higher-level needs for intellectual 
achievement, aesthetic appreciation, and, finally, self-actualization. According to Maslow, self-actualized people are fulfilled people. They perceive reality easily and are comfortable with it. They accept themselves and others. They feel free to think and act spontaneously. They approach problems with no personal biases. They value time they can spend by themselves as well as time they spend with others. Their thinking is not rigidly tied to cultural values, and they feel brotherhood among all human beings. They enjoy a small number of rich relationships with people of both sexes. They enjoy work involved in reaching goals. They are relatively free of prejudice and jealousy. They have a sense of humor and the ability to be creative.

Maslow called the four lower-levels needs-survival, safety, belonging, and esteem-deficiency needs. When these needs are not met, motivation increases to find ways of satisfying them. When they are satisfied, the motivation for fulfilling them decreases. Maslow labeled the three higher level needs-intellectual achievement, aesthetic appreciation, and self-actualization-being needs. When they are met, a person's motivation does not cease; instead, it increases to seek further fulfillment. Unlike deficiency needs, being needs can never be completely fulfilled.

Maslow's theory can provide important information for understanding motivation. Even so, it has been criticized because people do not always appear to behave as the theory would predict. Most of us move back and forth among different types of needs and may be motivated by different needs at the same time. Regardless of criticism, Maslow's hierarchy does provide a way of looking at the full person, whose physical, emotional, and intellectual needs are interrelated.

\section{Cognitive Theory}

One of the central assumptions in cognitive theory is that individuals are motivated by variables other than external events or physical conditions such as hunger. When we succeed or fail at a task, we naturally think about who or what was behind our success or failure. We look to assign responsibility, and to understand the causes of our performance. We make attributions about who or what was responsible for how we performed. Attributions also are the source of our feeling good, bad, or indifferent after we succeed or fail.

Attributions can be classified along three dimensions: the source (locus) of control, stability, and controllability (Weiner, 1986). The source of control can be either internal or external. Saying that you did well on a test because you're good in math is an example of attributing success to an internal characteristic-ability. If you believe you did well because the teacher was lenient, you are attributing your success to an external factor--the teacher.

Stability, or the lack of it, is another characteristic of attribution. Suppose you fail an exam. An unstable attribution might refer to effort (I didn't study as much as I should have). A stable attribution might refer to perceived discrimination on the part of the teacher (she's always tough on girls).

Attributions also vary along a dimension called "controllability." If you believe that the difficulty of the task was responsible for your failure (I didn't do well because the questions were too hard), you're describing a cause beyond your control. If you failed the test because you lost your notes and couldn't study, you're attributing your failure to a factor that you can control.

The internal/external dimension seems to be closely related to feelings of confidence, self-esteem, pride, guilt, or shame. If success or failure is attributed to internal factors (i.e., skill, effort), success will lead to pride and increased motivation, whereas failure will lead to shame. If the causes are seen as external, gratitude could follow success and anger could follow failure. This dimension is closely related to Rotter's (1954) idea of locus of control. Sometimes individuals believe they are responsible for their own fate and like to work in situations where skills and effort can lead to success. Other people tend to have an external locus of control and generally believe that people and forces outside of themselves control their lives. These individuals prefer to work in situations where luck determines the outcome.

The stability dimension seems to be closely related to expectations about the future. If, for example, students attribute their success (or failure) to stable factors such as ability or difficulty of the test, they are likely to expect to succeed (or fail) on similar tasks in the future. But if they attribute the outcome to unstable factors such as mood or luck, they are likely to expect changes in the future when confronted with similar tasks.

The control dimension is related to both confidence and future expectations. A student who attributes a high grade on an American History exam to controllable factors takes pride in the grade and expects to achieve a similar grade on future tests. But if the student thinks the grade had very little or nothing to do with controllable factors (Boy, did I luck out!), he or she is likely only to feel grateful and hope that the good luck will continue. 
According to cognitive theory, how we classify attributions can affect our performance on future tasks. If you believe a failure is controllable (say, the result of low effort), you may be spurred by that failure to do better next time. If you believe, however, that you cannot control who or what caused the failure, you may not even try to improve your performance. Failure itself is not always harmful; what does the damage is attributing failure to causes over which you have no control.

A major component of cognitive theory that is related to locus of control is learned helplessness, described as the perception that one has no control over events. Learned helplessness develops when students or teachers believe that what happens has little or nothing to do with how much effort they expend (Abramson, Seligman, \& Teasdale, 1978). Many students from minority groups, poverty backgrounds, and special education settings develop extremely negative self-concepts when they perceive that no matter what they do or can do, their teachers expect them to do better or differently. Persistent students who are also higher achievers tend to attribute success to what they're doing. Low achievers and less persistent students more frequently attribute success to external causes. These are the students who tend to exhibit learned helplessness (Dweck, 1975).

Young children usually start school with high self-concepts. No one has taught them that they can't succeed. At first, when they have difficulty, they attribute it to bad luck or to the task at hand. Gradually, as they learn (or are told) through repeated exposure that they are incompetent, they learn to attribute failure to themselves (Buys \& Winefield, 1982). Internal attributions can cause students who feel helpless to have intense feelings of shame and self-doubt (Covington \& Omelich, 1981). At this point, whether students believe that they have failed because of external causes or lack of ability (internal causes), they're equally likely to believe in their helplessness and stop trying. Attribution patterns are fairly stable over time and situations, but training programs can break self-defeating attributions in students (Bar-Tal, Raviv, and Bar-Tal, 1982).

Covington and Beery (1976) described two types of students: success-oriented and failure-avoiding. Success-oriented students tend to believe that they can handle most academic challenges. They do not view ability as an important issue in learning. These students view success and failure as related to quality of efforts. Bar-Tal (1982) found that success-oriented students attribute success to ability and effort and failure to lack of proper effort. Success improves further confidence; failure signals a need to try harder. Success-oriented individuals are not threatened by failure when it does occur because it doesn't reflect on their ability. Failure can be used to motivate already successful students.

Failure-avoiding students tend to have a different set of attributes. They attribute failure to lack of ability and attribute success to external factors such as luck or easiness of the task (Weiner \& Kukla, 1970). These students blame themselves for failure but take little credit for success. They feel they have little control over their academic destiny. They try to minimize pain by trying to avoid failure. Severely failure-oriented students develop learned helplessness. The individual sees no relationship between effort and attainment of goals.

Attribution theory literature suggests that low-achieving students are not all unmotivated. Many are very motivated-but to avoid failure rather than to succeed. Teachers should spend more time learning about student beliefs about causes for success and failure. Kifer (1975) found that changes in locus of control and self-concept both occur gradually and with repeated experience with success or failure. One important goal is to establish classroom conditions in which students learn that proper effort can lead to success.

\section{Other Factors Influencing Motivation to Learn}

In addition to the theoretical perspectives described, several additional factors have been associated with the link between motivation and academic performance. These include (a) anxiety, (b) self-concept, (c) teacher expectations, (d) the learning process, (e) goal structure, and (f) incentives for learning.

\section{Anxiety}

Several behaviors of highly anxious students in learning situations account for their low performance levels. Hill and Wigfield (1984) found that highly anxious students respond similarly to those with learned helplessness; they tend to avoid failure because they fear negative evaluations. They avoid evaluative situations and choose easy tasks in which success is more certain. They also engage in failureavoiding strategies. Anxious students do not attend to tasks in sufficient detail; they are preoccupied with negative selfreferences or worry. As the teacher is presenting material, anxious students are likely to be thinking about inadequa- 
cies that may make attempts to learn the material more difficult.

Anxious students have difficulty when instructional methods require them to rely on short-term memory or when they are asked to perform quickly. They have difficulty learning material that is not well organized. Anxious students tend to perform better when the teacher structures information. Anxiety also may cause the student to have social and academic problems. Highly anxious students have lower self-concepts, blame themselves for failure, and daydream excessively.

\section{Self-Concept}

Self-concept-one's ideas or perceptions about oneself -is one of the most important single factors affecting behavior (Combs \& Avila, 1985). Educators have become increasingly aware of the impact that an individual's selfconcept and self-esteem have on classroom behavior and achievement. Students' problems in school may be solely attributable to the lack of a positive self-concept (Combs \& Avila, 1985).

The relationship between self-concept and achievement has been discussed extensively in the psychology literature. Students' self-concept can be an important aspect in understanding how they deal with academic tasks. Many students are caught in a vicious cycle; they believe they cannot perform well in a certain activity and they avoid it. Because they avoid it, they fail to get practice in the activity and do not perform well when they are asked to respond in class. The negative experience caused by the inability to respond correctly only reinforces their initial belief about their inability. This cycle becomes a self-fulfilling prophecy. A negative self-image can be self-perpetuating. Over time it can have a negative impact on academic achievement.

\section{Teacher Expectations}

Although debate and research continues, Rosenthal and Jacobson's (1968) investigation of teacher expectations does point out a serious concern. In the classroom a teacher's incorrect beliefs about a students' abilities or behaviors can bring about the behaviors the teacher expects. Several researchers have found that teacher expectations can influence student performance (Cornbleth, Davis, \& Button, 1974; Good, 1970: Pippert, 1969). Two kinds of expectation effects can occur: self-fulfilling prophecy and sustaining expectation effect.
Self-fulfilling prophecy occurs when teacher beliefs about students are incorrect, but student behavior comes to match the initially inaccurate expectation. The sustaining expectation effect occurs when teachers are fairly accurate in their assessment of student abilities and respond to students based on those judgments. The problem arises when students show some improvement but the teacher does not alter his or her expectations to take account of the improvement. The chance to raise expectations, provide more appropriate teaching and thus encourage higher student achievement is lost.

Good and Brophy (1984) found that once teachers have formed expectations about a student, they treat that student in accordance with those expectations. Students who are expected to achieve tend to be asked more and harder questions, are given more chances and longer time to respond, and are interrupted less often than students who are expected to do poorly (Allington, 1980; Cornbleth, Davis, \& Button, 1974; Good \& Brophy, 1984; Rosenthal, 1983).

Students for whom teachers have high expectations are given clues and prompts-communicating their beliefs that the student can answer the question (Rosenthal, 1983). Teachers tend to be more encouraging in general toward students for whom they have high expectations. They smile at these students more often and show greater warmth through nonverbal responses such as leaning toward the student and nodding their heads as students speak (Woolfolk and Brooks, 1982, 1985). In contrast, with students for whom expectations are low, teachers ask easier questions, allow less time for answering, and are much less likely to give prompts.

Good and Brophy (1984) noted that teachers demand better performance from high-achieving students, are less likely to accept a poor answer, and praise them more for good answers. Teachers are more likely, on the other hand, to accept or even reinforce inadequate answers from lowachieving students or criticize students for wrong answers. Low-achieving students receive less praise than highachieving students for similar correct answers. On tests when the answer is almost right, the teacher is more likely to give the benefit of the doubt (and better grade) to highachieving students (Finn, 1972).

This inconsistent feedback is confusing for low-ability students. Imagine how difficult it is to learn if your wrong answers are sometimes praised, sometimes ignored, and sometimes criticized, and your correct answer receives little recognition (Good, 1983). 
A student's achievement motivation, aspiration level, and self-concept may all be affected by teacher expectations. Many students use the teacher's behavior as a mirror in which to see themselves. If the reflection says they are incapable, self-esteem is likely to suffer. Brophy (1982) found that, in general, the self-esteem of students who are young, dependent, conforming, or who really like the teacher is the most likely to be affected by teacher views.

\section{The Learning Process}

Keller (1983) suggested that four major dimensions of the learning process affect motivation:

1. Interest-learner curiosity.

2. Relevance-learner perception that instruction is related to personal needs or goals.

3. Expectancy-learner-perceived likelihood of success and extent to which the student views success as being under personal control.

4. Satisfaction-a learner's intrinsic motivation and reaction to extrinsic rewards.

Clearly, for learning to occur, one must pay attention to a stimulus. According to Keller, interest is more likely to be maintained if curiosity is stimulated and if students have an opportunity to explore and manipulate various objects physically or intellectually. Personal motivation also will increase when individuals perceive that an instructional task will satisfy a basic need, motive, or value. An individual's expectation for success or failure also can affect performance.

Teachers can increase expectations for success by providing successful experiences on meaningful, not trivial or easy, tasks. They also can use instructional strategies that offer students personal control over success. Feedback that helps students relate success to personal ability and effort also may increase student motivation.

In general, students benefit from feedback and information that has pleasurable rather than aversive consequences. They enjoy having the opportunity to make decisions and to be rewarded occasionally for tasks for which they are at least partiallỳ responsible.

\section{Goal Structure}

Johnson and Johnson $(1978,1987)$ have found that motivation can be influenced greatly by the ways in which we relate to the other people who are also involved in accomplishing a particular goal. Johnson and Johnson have labeled this interpersonal factor the goal structure of the task. The three basic structures are: cooperative, competitive, and individualistic.

Cooperative Students work together to accomplish shared goals.

Competitive Students work against each other to achieve goals that only a few students can attain.

Individualistic One student's achievement of the goal is unrelated to other students' achievement of the goal.

Several studies have shown that when the task involves complex learning and problem-solving skills, cooperation leads to higher achievement than does competition, especially for low-ability students (Davis, Laughlin, \& Komorita, 1976; Edwards \&DeVries, 1974; Slavin, 1977). Johnson and Johnson (1987) found that cooperative settings are more likely to produce higher levels of motivation to learn, because interaction patterns encourage and support efforts to achieve. Their research has shown improved learning in cross-ethnic and cross-handicapped groupings. Many experts have pointed out detrimental effects of competition in the classroom. Holt (1982) found that students who fear failure in competitive situations spend most of the day figuring out strategies to protect themselves in the classroom. Competition appears to motivate students to avoid failure rather than to focus on learning.

All three goal structures are effective under certain conditions and are relevant to specific goals and objectives of a lesson. Knowing when to use cooperative, competitive, and individualistic learning is an important instructional decision that teachers must make.

\section{Incentives for Learning}

Not every lesson successfully completed will enhance a sense of competence. Some activities necessarily involve drill and repetition. A student may feel competent enough to not have any intrinsic interest in working on the task to improve his or her competence. In this case, the teacher may decide to provide extrinsic reinforcement for successful completion of work.

Some students-those with less ability, a low need for achievement, inadequate preparation, a history of failing a particular subject, or a poor academic self-concept-may need extra incentives at the outset in order to tackle what, for them, is a difficult task. In these situations the teacher 
may plan the lesson to include systematic reinforcement. Caution should be observed, however, because external rewards used inappropriately can undermine students' natural interest in a subject (Cohen, 1985; Deci, 1975).

\section{REMEDIAL STRATEGIES TO INCREASE MOTIVATION}

Apparent lack of motivation in a student may result from a variety of underlying reasons such as those postulated in the theories and factors just described. Unfortunately, there is no panacea or cure-all for motivation deficits. Various intervention approaches have been described in the education and psychology literature. Several of these suggested techniques and strategies will be described. Initially, however, teachers may want to consider interacting closely with the student to attempt to get a better feel for the conditions that may be at the heart of the motivation deficit. The Teacher-Student Motivation Planning Form (Figure 2) may provide an appropriate format for teacher-student interaction.

\section{Teacher-Student Motivation Planning Form}

The Teacher-Student Motivation Planning Form provides a format for recording and monitoring decisions about motivation planning, as well as information about the student's present level of performance. This is given in Figure 2. Some parts of the form are to be completed prior to a teacher-student conference; others are to be completed after intervention, when results and possible revised plans are being made. Teachers are urged to fill in each part of the form so that it will provide as complete a profile as possible.

The Teacher-Student Motivation Planning Form consists of the following sections: General Information, Current Student Behavior, Desired Student Behavior, Teacher's Attributions, Student's Attributions, Previous Plan and Results, Current Plan, Results, and Revised Plan.

\section{General Information}

This part of the form provides space for the student's name, school, date of birth, age, grade in school or specific class period, teacher's name, and the current date.

\section{Current Student Behavior}

The teacher's goal for this student behavior is to be stated; for example, "To pass this course, Bill must turn in each homework assignment."

\section{Teacher's Attributions}

Performance is the only visible indicator of achievement motivation. When a student succeeds or fails at a task, we naturally think about who or what was behind the success or failure. Here the teacher would describe his or her own attributions about the current student behavior. Teachers may attribute student success to the student's home conditions, effort, interest, and their own teaching skill. The teacher must honestly look at his or her perception of the student behavior. Often, teachers will see a variety of interrelated factors-some of which the teacher can control (length of assignment, reinforcers, grading procedures) and those he or she cannot (student's physical health, parental cooperation, and lack of time for homework because of employment or family demands).

\section{Student's Attributions}

During a conference situation, in which a sense of rapport and true nonthreatening concern have been expressed, the student is asked for attributions concerning the behavior. Students probably will attribute their performance to some combination of effort, ability, mood, task difficulty, and luck. Teachers are cautioned to record the student's answers without judgmental responses or facial expressions.

\section{Previous Plan and Results}

Unfortunately, many students have a long history of social and academic behaviors that interfere with success. In this section teachers should list any previous classroom intervention to modify this behavior. They will want to probe the student and professional colleagues about previous attempts to modify this type of behavior. For example, an explanation of past token economies and contingency management techniques could be described, along with their results. If previous attempts have failed, the teacher will want to carefully consider whether other similar measures would be successful.

The teacher also may gain important insights on how to modify previously unsuccessful techniques. The student should be asked about the success or failure of previous interventions. Often the student's perception of these attempts adds anecdotal information that will guide the planning process.

\section{Current Plan}

After completing the previous sections, the teacher and student collaboratively decide on a course of action. A real- 
Student:

Date of Birth:

Teacher:

Current Student Behavior:

Desired Student Behavior:

Teacher's Attributions:

Student's Attributions:

Previous Plan (if any) and Results:

Current Plan:

Realistic Short-Term Goal:

Modifications Necessary for Success:

Assessment:

Next Conference Date:

Results:

Revised Plan (if necessary):
School:

Grade/Class:

Date: 
istic short-term goal must be agreed upon. In most cases teachers cannot expect a complete reversal of current student behavior overnight. Likewise, students cannot expect to continue an undesirable classroom behavior without at least some modification. Once again, an atmosphere of mutual respect and commitment to change will facilitate the creation of a realistic goal.

Usually some modifications will have to be considered if a realistic short-term goal is to be reached. As an example, the teacher might give serious consideration to the types of homework being assigned. Because homework is designed as an independent activity, a student may need more time in teacher-directed and dependent activities before this type of homework can be completed.

The assessment phase of the current plan should state how both teacher and student will record the progress or lack of progress; for example, "Both Bill and Mrs. Jones will record each math assignment at the beginning of class." Having the student record his or her own performance helps put ownership of the realistic short-term goal with the student.

The last decision to be made in this section is to schedule a future conference to discuss the results. Because this planning form is geared to realistic short-term goals, a subsequent conference probably should be scheduled within days or weeks of the plan's implementation.

\section{Results}

This section should include a descriptive analysis of the plan's effectiveness, along with supporting data. If the results show that the short-term goal has not been met, the teacher should go on to the next section, Revised Plan.

\section{Revised Plan}

The process is repeated. A new conference would be held, during which both the student and the teacher formulate a new strategy with particular emphasis on not repeating the parts of the previous plan that contributed to its failure.

\section{Guidelines for Classroom Motivation}

Once teachers have a clearer idea of variables influencing current student motivation and performance in the classroom, more appropriate goals and intervention strategies can be targeted. Although many educators and cognitive psychologists now believe that children are responsible for their own learning (Reid \& Hresko, 1981), classroom teachers still control the vast majority of instructional variables. Various strategies and techniques that have been presented in the education and psychology literature on student motivation are discussed next. These guidelines have proven effective for some students in some situations.

\section{Competitive, Noncompetitive, and Cooperative Learning Structures}

Some students thrive in situations in which competition is essential for success. A spelling bee or a multiplication fact card game with only one "real winner" are two examples of competitive classroom structures. When all participants are evenly matched, a competitive game or contest can be exciting and rewarding for all, especially if winners are likely to change from one match to the next.

Noncompetitive structures emphasize individual learning and individual effort. In a sense, students do compete, but only with their own past performance. This kind of structure allows for more winners and permits a greater number of students to feel competent.

In a cooperative learning structure, students usually work in small groups for group rewards. All members of a group, both high and low achievers, learn to work together for rewards that each member will share. When properly introduced and supervised, this type of classroom arrangement can be successful. Optimally, cooperative learning allows each student to display his or her strength while becoming more aware of the needs of others.

Choosing a competitive, noncompetitive, or cooperative learning structure is an individual teacher decision. Different activities within any given day may successfully incorporate one or more structures. Certainly the world outside the classroom demands a shift from structure to structure. Why should the child's world within the classroom be any different?

\section{Unidimensional and Multidimensional Classrooms}

Rosenholtz and Simpson (1984) have stated that most teachers expect all students to be working on similar tasks at any given time. Even in classrooms for children with special needs, teachers typically expect this same type of conformity, albeit with more individual flexibility than regular classrooms. This type of classroom is commonly referred to as "unidimensional."

Unidimensional classrooms can be stressful for students who are performing significantly above or below the nor- 
mal range of achievement. Often, teachers unknowingly contribute to this stress by placing an individual student in an activity that he or she is developmentally unprepared to master. Hudson, Colson, and Braxdale (1984) have proposed a hierarchy of levels of teacher presentation to match each child's current level of functioning. For example, one student may recall the capital of Kansas as Topeka, while another may need several choices because he or she is functioning at the lower recognition level.

In multidimensional classrooms, individual students often work on different tasks. The key to success in these types of classrooms rests on the accuracy of assessment information gathered on individual students. Norm-referenced tests, which provide scores that are mistakenly matched to grade-level curricula, further complicate teachers' attempts to structure successful multidimensional classrooms. Current curriculum-based assessment tools, such as the Hudson Education Skills Inventory (Hudson, Colson, Welch, Banikowski, \& Mehring, 1989), give teachers more accurate information to plan appropriate instruction for a wide range of student performance within the same classroom.

\section{Intrinsic and Extrinsic Reinforcers}

During various activities some students appear to be unaffected by environmental variables. Motivation without apparent reward is called intrinsic. Some theorists believe that intrinsically motivated students have developed selfreinforcement processes that can be traced back to some earlier, external reinforcer. For example, a student may have initially turned in assignments in the best handwriting because the teacher rewarded this effort with a sticker or praise. Now this same student may turn in the same quality penmanship for internal feelings of satisfaction of a job well done.

Children with special needs may require a varied menu of both intrinsic and extrinsic rewards. Too often, educators insist that classroom rewards be either all intrinsic or all extrinsic. Motivating all behavior with extrinsic rewards can set up unrealistic expectations for the child outside the classroom. Likewise, asking students to rely solely on intrinsic motivators hardly approximates life for most adults. How many workers would continue to be effective for purely intrinsic rewards, forsaking paychecks and praise from co-workers and supervisors?

Systematic reinforcement, in the form of teacher praise, free time, or the chance to play educationally relevant games, may make school life more pleasant and may assist students to become more involved in learning. Token economies also have been found to be effective in improving the academic and social behaviors of many exceptional students (McLaughlin, 1975; O'Leary \& Drabman, 1971). Cohen (1973) and others have found contingency management contracting to be a particularly effective method of external motivation at the secondary level.

\section{Motivational Techniques in Teaching}

Gage and Berliner (1988) have listed 15 techniques that are supported by research as increasing motivation in the classroom.

1. Begin the lesson by giving students a reason to be motivated.

2. Tell students exactly what you want accomplished.

3. Have students set short-term goals.

4. Give verbal and written praise.

5. Use tests and grades judiciously.

6. Capitalize on the arousal value of suspense, discovery, curiosity, and exploration.

7. Occasionally do the unexpected.

8. Whet the appetite.

9. Use familiar material for examples.

10. Use unique and unexpected contexts when applying concepts and principles.

11. Make students use what they have previously learned.

12. Use simulations and games.

13. Minimize the attractiveness of competition.

14. Minimize any unpleasant consequences of student involvement-i.e., use positive reinforcement.

15. Understand the social climate of the school. (pp. 378-389)

Dembo (1988) suggested several additional classroom applications for enhancing student motivation:

1. Focus and maintain student attention through arousing student curiosity. This can be accomplished by introducing something that is novel, different, or unusual.

2. Consider varying levels of ability in students, and encourage them to put forth maximum effort consistent with their ability. Differentiated assignments, materials, and evaluation standards will assist students to set more realistic aspirations. Assisting stu- 
dents to experience success will lead to increased achievement motivation.

3. When students do not experience success, give feedback in the form of concrete steps that will lead to improvement.

4. Actively involve students in the learning process. Provide them with opportunities to "select activities, assignments, due dates, and those with whom they work, as well as their own methods and pace of learning" (p. 210).

5. Reduce anxiety by providing sufficient time to complete assignments, tests, and other work.

Structured learning situations rather than independent study, discussion groups, or other types of student-directed learning activities also may be beneficial. Diagrams, outlines, and other organizational strategies also can aid in reducing anxiety. Teaching students relaxation techniques may be an additional option. Dembo's most important suggestion is that teachers should not wait for students to become motivated; the teacher should $a c t$ !

Brophy and Kher (1985) suggested that in order to develop positive motivation, negative attitudes must be eliminated. Specific strategies for overcoming negative attitudes include the following:

1. Be a patient, encouraging teacher who supports learning efforts.

2. Provide an appropriate match between student ability and task difficulty.

3. Provide tasks that are sufficiently varied and interesting.

4. Be a teacher who generally presents tasks as learning opportunities with which he or she will assist students rather than as ordeals to be endured to get good grades or to please the teacher. (p. 445)

\section{Increasing Achievement Motivation/ Improving Student Attributions}

Students with high achievement needs but equally high failure fears are likely to select relatively easy, clearly manageable tasks. Students with high achievement motivation, and little fear of failure are likely to select tasks that more fully test their limits. Teachers can help students engage in goal-relevant tasks by reducing fear of failure, helping to develop positive achievement motivation, and manipulating task incentives. Differential assignments also may have major effects on student performance. It is critical to help students perceive the relationship between their efforts and success. One way to facilitate this perception is to teach students how to explain success or failure on the basis of actual causal factors (I failed the test because I went to the ballgame last night instead of studying) rather than on the basis of habit (I failed because I'm stupid). Assisting students in learning how to set realistic goals also improves motivation and positive attributions toward learning.

\section{Peer Tutoring}

Buddy systems or peer tutoring can be used to effectively motivate student behavior. This technique has the added advantage of allowing peer tutors to be responsible for assisting other students and increasing their own subject matter knowledge. Training peer tutors through teacher modeling or role playing appropriate tutoring behaviors increases the effectiveness of the peer tutoring model.

\section{Motivation Strategies}

Good and Brophy (1986) described forty specific strategies which could be implemented in classrooms to improve motivation. Since this listing is far too numerous and detailed to summarize in this article, the reader is encouraged to go directly to the source listed in the reference section. Strategies are grouped into five major categories including: task design and selection strategies, strategies that involve imposing external reward systems, effective instruction strategies, success oriented strategies, and metacognitive strategies.

Van Reusen, Box, Schumaker, and Deshler (1987) designed an Educational Planning Strategy. The initial goal of this strategy was to train students to be more actively involved in the development of their individualized educational programs. The skills acquired as the result of instruction in this strategy, in addition, would assist most students to be more knowledgeable about their own learning and social strengths and weaknesses and equip them with specific skills to interact more confidently in a variety of settings. The strategy has proven to be effective in assisting students to take a more active role in decision making.

\section{SUMMARY}

Current research indicates a strong correlation between motivation and effective learning in regular and special needs students. Research also tells us that motivation levels can be changed over time. Before embarking on an inter- 
vention plan, however, teachers may find value in reviewing basic theories of motivation in an attempt to detect variables that may be affecting student motivation. The Teacher-Student Motivation Planning Form provides a format and process that teachers might use to facilitate this investigation. Once factors influencing student motivation are identified, alternative strategies may be implemented to influence students' active involvement in the learning process. There is no single motivation-enhancing intervention approach. Different techniques or strategies are effective with each student. Methods also may have to be varied over time or as effectiveness decreases. Reemphasis of Dembo's (1988) comment is an appropriate summary statement: Teachers should not wait for students to become motivated: They should act!

\section{REFERENCES}

Abramson, L., Seligman, M., \& Teasdale, J. (1978). Learned helpless in humans: Critique and reformulation. Journal of Abnormal Psychology, 87, 49-74.

Adelman, H. S., \& Taylor, L. (1983). Learning disabilities in perspective. Glenview, IL: Scott, Foresman.

Adelman, H. S., \& Taylor, L. (1984). Enhancing motivation for overcoming learning problems. Annual Review of Learning Disabilities, 2, 102-109.

Allington, R. (1980). Teacher interruption behaviors during primary-grade oral reading. Journal of Educational Psychology, 71, 371-377.

Bar-Tal, D. (1982). The effects of teachers' behavior on pupils' attributions: A review. In C. Antaki \& C. Brieson (Eds.), Attribution and psychological change: A guide to the use of attribution theory in the clinic and the classroom. London: Academic Press.

Bar-Tal, D., Raviv, A., \& Bar-Tal, Y. (1982). Consistency of pupil's attributions regarding success and failure. Journal of Educational Psychology, 74, 104-110.

Brophy, J. E. (1982, March). Research on the self-fulfilling prophecy and teacher expectations. Paper presented at annual meeting of American Educational Research Association, New York.

Brophy, J., \& Kher, N. (1988). Teacher socialization as a mechanism for developing student motivation to learn. In R. Feldman (Ed.), Social psychology applied to education. Cambridge: Cambridge University Press.

Buys, N., \& Winefield, A. (1982). Learned helplessness in high school students following experience of non-contingent rewards. Journal of Research in Personality, 16, 118-127.

Cohen, H. L. (1973). Behavior modification and socially deviant youth. In C. E. Thorenson (Ed.), Behavior modification in education: Seventy-second yearbook of the National Society for the Study of Education (Part 1). Chicago: University of Chicago Press.

Cohen, M. (1985). Extrinsic and intrinsic motivation. In M. Alderman \& M. Cohen (Eds.), Motivation theory and practiced for preservice teachers (pp. 6-15). Washington, DC: Eric Clearinghouse on Teacher Education.

Combs, A. W., \& Avila, D. L. (1985). Helping relationships: Basic concepts for the helping professions (3rd ed.). Boston: Allyn \& Bacon.
Cormbleth, C., Davis, O. L., \& Button, C. (1974). Expectations for pupil achievement and teacher-pupil interaction. Social Education, 38, 54-58.

Covington, M., \& Beery, R. (1976). Self-worth and schooling. New York: Holt, Rinehart \& Winston.

Covington, M., \& Omelich, C. (1981). As failures mount: Affective and cognitive consequences of ability demotion in the classroom. Journal of Educational Psychology, 71, 796-808.

Davis, J., Laughlin, P., \& Komorita, S. (1976). The social psychology of small groups: Cooperative and mixed-motive interaction. In $\mathbf{M}$. Rosenzweig \& L. Porter (Eds.), Annual Review of Psychology, 27, 501-542.

Deci, E. (1975). Intrinsic motivation. New York: Plenum.

Dembo, M. H. (1988). Applying educational psychology in the classroom (3rd ed.). New York: Longman.

Deshler, D., Schumaker, J., \& Lenz, K., (1984). Academic and cognitive interventions for LD adolescents. Annual Review of Learning Disabilities, 2, 57-66.

Dweck, C. (1975). The role of expectations and attributions in the alleviation of learned helplessness. Journal of Personality \& Social Psychology, 31, 674-685.

Edwards, K. J., \& DeVries, D. L. (1974). The effects of teams-games-tournament and two instructional variations on classroom student attitudes, and student achievement (Rep. No. 172). Baltimore: Center for Social Organization of Schools, Johns Hopkins University.

Finn, J. (1972). Expectations and the educational Environment. Review of Educational Research, 42, 387-410.

Gage, N. L., \& Berliner, D. C. (1988). Educational psychology (4th ed.). Boston: Houghton Mifflin.

Good, T. (1970). Which pupils do teachers call on? Elementary School Journal, 70, 190-198.

Good, T. (1983). Recent classroom research: Implications for teacher education. An invited address delivered at annual meeting of American Association of Colleges for Teacher Education, Chicago.

Good, T., \& Brophy, J. (1984). Looking in classrooms. New York: Harper \& Row.

Good, T. L., \& Brophy, J. E. (1986). Educational psychology (3rd ed.). New York: Longman.

Hallahan, D. P., \& Kauffman, J. (1988). Exceptional children: Introduction to special education (4th ed.). Englewood Cliffs, NJ: PrenticeHall.

Hill, K. T., \& Wigfield, A. (1984). Test anxiety: A major educational problem and what can be done about it. Elementary School Journal, 85, 105-126.

Holt, J. (1982). How children fail. New York: Delta.

Hudson, F., Colson, S., \& Braxdale, C. (1984). Instructional planning for dysfunctional learners: Levels of presentation. Focus on Exceptional Children, 17(3), 1-12.

Hudson, F., Colson, S., Welch, D., Banikowski, A., \& Mehring, T. (1989). Hudson educational skills inventory. Austin, TX: PRO-Ed.

Johnson, D., \& Johnson, R. (1978). Many teachers wonder . . . will the special needs child ever really belong? Instructor, 87, 152-154.

Johnson, D., \& Johnson, R. (1987). Learning together and alone: Cooperative, competitive, and individualistic learning (2nd ed.). Englewood Cliffs, NJ: Prentice-Hall.

Keller, J. (1983). Motivation design of instruction. In C. Reigeluth (Ed.), Instructional-design theories and models: An overview of their current status. Hillsdale, NJ: Erlbaum. 
Kifer, E. (1975). Relationships between academic achievement and personality characteristics: A quasi-longitudinal study. American Educational Research Journal, 12, 191-210.

MacMillan, D. (1982). Mental retardation in school and society (2nd ed.). Boston, MA: Little, Brown.

Madsen, K. B. (1973). Theories of motivation. In B. B. Wolman (Ed.), Handbook of general psychology. Englewood Cliffs, NJ: PrenticeHall.

Maslow, A. H. (1970). Motivation and personality (2nd ed.). New York: Harper and Row.

McDougall, W. (1908). An introduction to social psychology. London: Methuen.

McLaughlin, T. F. (1975). The applicability of token reinforcement systems in public school systems. Psychology in the Schools, 12, 84-89, 369-370.

Murray, H. A. (1938). Explorations in personality. New York: Oxford University Press.

O'Leary, K. D., \& Drabman, R. S. (1971). Token reinforcement programs in the classroom: A review. Psychological Bulletin, 75, 379-398.

Paget, K. D., Nagle, R. J., \& Martin, R. P. (1984). Interrelationships between temperament characteristics and teacher-student interactions. Journal of Abnormal Child Psychology, 12, 547-560.

Pippert, R. A. (1969). A study of creativity and faith (Monograph No. 4). Manitoba Department of Youth and Education.

Polloway, E. A., \& Epstein, M. H. (1985). Current research issues in mild mental retardation: A survey of the field. Education \& Training of the Mentally Retarded, 20, 171-174.

Polloway, E. A., \& Smith, J. D. (1983). Changes in mild mental retardation: Population, programs, and perspectives. Exceptional Children, 50, 149-159.

Pullis, M., \& Cadwell, J. (1985). Temperament as a factor in the assessment of children educationally at risk. Journal of Special Education, 19, 91-102.

Reid, D. K., \& Hresko, W. P. (1981). A cognitive approach to learning disabilities. Austin, TX: PRO-Ed.

Reschly, D. (1987 ). Learning characteristics of mildly handicapped students: Implications for classification, placement, and programming. In M. C. Wang, M. C. Reynolds, \& H. J. Walberg
(Eds.), Handbook of special education: Research and practice-Learner characteristics and adaptive education (Vol. 1). New York: Pergamon Press.

Robinson, N., \& Robinson, H. (1976). The mentally retarded child (2nd ed.). New York: McGraw-Hill.

Rosenholtz, S. J., \& Simpson, C. (1984). The formation of ability conceptions: Developmental trend or social construction? Review of Educational Research, 54, 31-63.

Rosenthal, R. (1983). The Pygmalion effect lives. Psychology Today, pp. 56-63.

Rosenthal, R., \& Jacobson, L. (1968). Pygmalion in the classroom: Teacher expectation and pupils' intellectual development. New York: Holt, Rinehart \& Winston.

Rotter, J. (1954). Social learning and clinical psychology. Englewood Cliffs, NJ: Prentice-Hall.

Slavin, R. (1977). Classroom reward structure: An analytic and practical view. Review of Educational Research, 47, (4), 633-640 (Rep. No. 172). Baltimore: Center for Social Organization of Schools, Johns Hopkins University.

Sprinthall, N. A., \& Sprinthall, R. C. (1987). Educational psychology: A developmental approach (4th ed.). New York: Random House.

Van Reusen, T., Box, C., Schumaker, J., \& Deshler, D. (1987). The education planning strategy. Lawrence, KS: EXCELLENTerprises.

Weiner, B. (1986). An attributional theory of motivation and emotion. New York: Springer- Verlag.

Weiner, B., \& Kukla, A. (1970). An attributional analysis of achievement motivation. Journal of Personality \& Social Psychology, 15, 1-20.

Woolfolk, A. E., \& Brooks, D. (1982). Nonverbal communication in teaching. In E. Gordon (Ed.), Review of research in education (Vol. 10). Washington, DC: American Educational Research Association.

Woolfolk, A. E., \& Brooks, D. (1985). The influence of teachers' nonverbal behaviors on students' perceptions and performance. Elementary School Journal, 85, 514-528.

Zigler, E. (1962). Rigidity in the feeble-minded. In E. P. Trapp \& P. Himelstein (Eds.), Readings on the exceptional child (pp. 141162). New York: Appleton-Century Crofts. 


\section{STATISTICAL UPDATE: Number of Learning Disabled Children 3-21 Years Old Served By Educational Environments School Year 1986-1987}

\begin{tabular}{|c|c|c|c|c|c|c|c|c|c|}
\hline STATE & $\begin{array}{l}\text { REQULAR } \\
\text { CLASSES }\end{array}$ & $\begin{array}{l}\text { RESOURCE S } \\
\text { ROOM }\end{array}$ & $\begin{array}{l}\text { SEPARATE } \\
\text { CLASSES }\end{array}$ & $\begin{array}{l}\text { PUBLIC } \\
\text { SEPARATE } \\
\text { FACILITY }\end{array}$ & $\begin{array}{l}\text { PRIVATE } \\
\text { SEPARATE } \\
\text { FACILITY }\end{array}$ & $\begin{array}{l}\text { PUBLIC } \\
\text { RESIDENTIAL } \\
\text { FACILITY }\end{array}$ & $\begin{array}{l}\text { PRIVATE } \\
\text { RESIDENTIAL } \\
\text { FACILITY }\end{array}$ & $\begin{array}{l}\text { HONEBOUND } \\
\text { HOSPITAL EN- } \\
\text { VIRONWENT }\end{array}$ & $\begin{array}{l}\text { CORRECTION } \\
\text { FACILITIES }\end{array}$ \\
\hline ALABAMA & - & 27,168 & 1,541 & 0 & 22 & - & 198 & 0 & 75 \\
\hline ALASKA & 2,437 & 3,068 & 1,110 & 0 & 0 & 3 & 0 & 13 & 0 \\
\hline ARIZONA & 166 & 22,463 & 5,156 & 0 & 11 & $\theta$ & 7 & 0 & 1 \\
\hline ARKANSAS & 3,948 & 17,682 & 1,132 & 13 & 32 & 1 & 14 & 25 & 126 \\
\hline CALIFORNIA & 5,535 & 147,948 & 65,726 & - & 737 & - & - & - & 219 \\
\hline COLORADO & 3.182 & 17,636 & 1,638 & 19 & 27 & $\theta$ & 9 & 14 & 59 \\
\hline CONNECTICUTT & 2,522 & 20,248 & 6,496 & 229 & 230 & 36 & 53 & 25 & 10 \\
\hline DELAWARE & 1,683 & 3,562 & 1,218 & 550 & 2 & 1 & 5 & 18 & $\theta$ \\
\hline DISTRICT OF COLLMEIA & 0 & 3,058 & 3 & 177 & 138 & 0 & 4 & 0 & 23 \\
\hline FLORIDA & 9,653 & 43,340 & 16,435 & 676 & 15 & 0 & 5 & 9 & 57 \\
\hline CEORGIA & 261 & 21,248 & 4.241 & 3 & 2 & 0 & 5 & 8 & 25 \\
\hline HAWAII & 2,445 & 3,920 & 1,041 & 0 & 2 & 3 & 0 & 0 & 15 \\
\hline IDAHO & 4,984 & 4,436 & 10 & 183 & 0 & 0 & 0 & 0 & 1 \\
\hline ILLINOIS & 3,808 & 66,809 & 29,628 & 901 & 159 & 15 & 20 & 24 & 21 \\
\hline INDIANA & 815 & 25,763 & 8,424 & 62 & 0 & 1 & 1 & 2 & $\theta$ \\
\hline 10WA & 217 & 17,498 & 4.350 & - & - & $\theta$ & - & 4 & $\theta$ \\
\hline KANSAS & 15,001 & - & 1,684 & 59 & 8 & 1 & 25 & 15 & 35 \\
\hline KENTUCKY & 910 & 18,385 & 2,157 & 220 & 1 & $\theta$ & 0 & 34 & 26 \\
\hline LOUISIANA & 7,624 & 12.803 & 10,493 & 407 & 138 & 44 & 14 & 71 & 53 \\
\hline MAINE & 4,940 & 4,484 & 543 & 14 & 32 & $\theta$ & 6 & 9 & 42 \\
\hline MARYLAND & 13,718 & 13,406 & 17,473 & 270 & 115 & $\theta$ & 3 & 50 & 290 \\
\hline MASSACHUSETTS & 4,158 & 30,905 & 9,793 & 945 & 1,376 & 245 & 237 & 363 & 30 \\
\hline MICHIGAN & 24,129 & 28,011 & 13,635 & 775 & - & 6 & 20 & 128 & 182 \\
\hline MINNESOTA & 4.932 & 28,291 & 3,395 & 151 & - & 0 & - & 25 & 20 \\
\hline MISSISSIPPI & 6,140 & 13,476 & 4,631 & 89 & 0 & 0 & 0 & 19 & 9 \\
\hline MISSOURI & 557 & 38,262 & 4,717 & 0 & 624 & 0 & - & 15 & 228 \\
\hline MONTANA & 3,367 & 3,264 & 882 & 22 & 0 & 0 & $\theta$ & 2 & 6 \\
\hline NEBRASKA & 2,189 & 9,109 & 869 & 0 & 4 & 0 & - & 0 & 55 \\
\hline NEVADA & 1.611 & 5,834 & 637 & 9 & 0 & 0 & $\theta$ & 3 & 55 \\
\hline NEW MAMPSHIRE & 5.701 & 2,213 & 1,286 & 0 & 138 & 2 & 42 & 5 & 2 \\
\hline NEW JERSEY & 9,691 & 30,849 & 31,536 & 2,346 & 1,293 & 9 & 14 & 104 & 112 \\
\hline NEW MEXICO & 7.780 & 4,617 & 632 & 9 & 25 & - & $\theta$ & 1 & 19 \\
\hline NEW YORK & 1,052 & 80,401 & 62,105 & 6,933 & 513 & 8 & 132 & 280 & 193 \\
\hline NORTH CAROLINA & 15,721 & 24,570 & 3,624 & 108 & 14 & 0 & 1 & 3 & 54 \\
\hline NORTH DAKOTA & 4,297 & 761 & 156 & 31 & 1 & 1 & 2 & 2 & $\theta$ \\
\hline OHIO & 22,927 & 39,687 & 9,963 & 76 & 1,816 & 0 & $\theta$ & 23 & 231 \\
\hline OKLAHOAM & 14,194 & 15,245 & 956 & 11 & 2 & 63 & 1 & 10 & - \\
\hline ORECON & 14,419 & 10,270 & 1,139 & 1 & 67 & $\theta$ & 8 & 35 & 78 \\
\hline PENNSYLVANIA & 14,935 & 32,695 & 27.052 & 608 & 1.172 & 39 & 88 & 47 & 118 \\
\hline PUERTO RICO & 692 & 6,255 & 935 & 107 & 105 & 11 & 3 & 53 & 5 \\
\hline RHOOE ISLAND & 6,537 & 2,413 & 3,395 & 11 & 58 & 0 & 20 & 12 & 3 \\
\hline SOUTH CAROLINA & 2,056 & 18,219 & 4,242 & 54 & 0 & 0 & 1 & 8 & 99 \\
\hline SOUTH DAKOTA & 530 & 4,592 & 203 & $\theta$ & 0 & 1 & 7 & 1 & 1 \\
\hline TENNESSEE & 5,694 & 32,513 & 6,107 & 151 & 22 & 4 & 6 & 28 & 74 \\
\hline TEXAS & 4,098 & 122,962 & 16,928 & 5.933 & 296 & 131 & 1 & 6,430 & 225 \\
\hline UTAH & 6,350 & 9,746 & 1,028 & 6 & 0 & 0 & 0 & 29 & 1 \\
\hline VERAONT & 1,989 & 2,399 & 28 & 5 & 14 & 0 & 22 & 3 & 0 \\
\hline VIRGINIA & 8,646 & 24,199 & 12.836 & 130 & 117 & 6 & 51 & 16 & 116 \\
\hline WASHINGTON & 11,249 & 17,445 & 3,961 & 47 & 341 & $\theta$ & 0 & 30 & 139 \\
\hline WEST VIRGINIA & 5,991 & 11,032 & 2,336 & 0 & 0 & 3 & 1 & 9 & 31 \\
\hline WISCONSIN & 6,512 & 13,685 & 2,491 & 14 & 6 & 1 & 0 & 10 & 39 \\
\hline mroming & 1,878 & 2,959 & 194 & 2 & 0 & 1 & 3 & 7 & 1 \\
\hline MERICAN SAMOA & 0 & 0 & 0 & 0 & $\theta$ & 0 & 0 & 0 & 0 \\
\hline guan & 266 & 260 & 229 & 0 & 0 & 0 & $\theta$ & 0 & - \\
\hline NORTHERN MARIANAS & 44 & 62 & 2 & 0 & 0 & $\theta$ & 0 & 0 & B \\
\hline TRUST TERRITORIES & - & - & - & - & - & - & - & - & - \\
\hline VIRGIN ISLANDS & - & - & - & - & - & - & - & - & - \\
\hline BUR. OF INDIAN AFFAIRS & 370 & 2,663 & 293 & 12 & 6 & 0 & 0 & $\theta$ & 0 \\
\hline U.S. INSULAR AREAS & 304,531 & $1,162,789$ & 412,717 & 22,371 & 9,677 & 638 & 1,029 & 8,022 & 3,198 \\
\hline 50 STATES, D.C. \& P.R. & . 303,871 & $1,159,804$ & 412,193 & 22,359 & 9,677 & 638 & 1,029 & 8.022 & 3,198 \\
\hline
\end{tabular}

Source: From Eleventh Annual Report to Congress on the Implementation of the Education of the Handicapped Act (p. A-40), 1989, U.S. Department of Education. Data as of October 1, 1988. 


\section{Professional update}

\section{Association for Children and Adults with Learning Disabilities}

February 21-24, 1990

Anaheim Hilton Hotel

Anaheim, California

Contact: ACLD (412) 341-1515

\section{Council for Exceptional Children}

April 23-27, 1990

Toronto, Ontario, Canada

Contact: CEC

1920 Association Drive

Reston, Virginia 22091

\section{American Association on Mental Retardation}

May 27-31, 1990

Atlanta, Georgia

Contact: AAMD (202) 387-1968

\section{NEW BOOKS}

Negotiating the Special Education Maze: A Guide for Parents and Teachers

by Winifred Anderson, Stephen Chitwood, and Diedre Hayden

This new second edition is completely revised and updated. It shows parents how to be educational advocates for their children and encourages them to be equal partners in all decisions that affect their child's education. It tells how the school systems work, the services available, and explains rights and benefits. It includes checklists, exercises, and charts to help parents. It is published by Woodbine House, 5615 Fishers Lane, Rockville, MD 20852.

\section{Improving Classroom Behaviour: New Directions for Teachers and Pupils}

\section{by Denis Mongon and Susan Hart}

This book is about children whose behavior causes distress in the schools. It suggests teachers, parents, and administrators must work together. The book provides a framework, a format, and a structure, with a continuing process of exploration and discovery. The book was written by authors from London and gives a perspective that serious professionals will want to examine. It is available from Teachers College Press, Columbia University, New York, NY 10027. 